\title{
mgr Monika Gzik*
}

\section{MINIMALIZACJA RYZYKA JEDNOOSOBOWEJ DZIAŁALNOŚCI GOSPODARCZEJ W KONTEKŚCIE UREGULOWAŃ PRAWNYCH W POLSCE}

\author{
MINIMISING THE RISK OF SOLE PROPRIETORSHIP IN THE CONTEXT \\ OF REGULATIONS IN POLAND
}

\begin{abstract}
In the light of the act on the freedom of economic activity, private persons may run a single proprietorship business and act independently as entrepreneurs. This institution, as the most common form of undertaking business activity in Poland, fills a significant fragment of the labor market space. The formal requirements of running a single economic enterprise are basically minimal. The form seems to be convenient for a beginner entrepreneur. However, the growing one-man business can carry a number of legal or financial risks. The article pointed out main problems related to functioning of sole proprietorship in the context of regulations in Poland. As examples of minimizing the risk, solutions in the form of mediation, contractor's financial credibility analysis, collateral of receivables and transforming into a commercial law company were offered.
\end{abstract}

Keywords: economic enterprise, single economic enterprise, business risk, risk minimization

JEL classification: K22, L26

* Uniwersytet Łódzki, Wydział Ekonomiczno-Socjologiczny, Katedra Pracy i Polityki Społecznej; monikagzik23@gmail.com 


\section{Wstęp}

Współczesny rynek pracy tworzy przestrzeń zróżnicowaną. Osoby fizyczne mają do wyboru różne formy organizacyjne prowadzenia działalności gospodarczej. Mogą prowadzić działalność z innymi osobami w ramach form dopuszczonych przez przepisy prawa. Mogą również prowadzić działalność jednoosobowo, występując wówczas samodzielnie jako przedsiębiorcy. Instytucja jednoosobowej działalności gospodarczej wypełnia zatem element wspomnianej wcześniej przestrzeni rynku pracy. Działalność jednoosobowa jest najpowszechniejszą formą działalności gospodarczej w Polsce. Zgodnie z Danymi Centralnego Środka Informacji Gospodarczej, w 2015 roku zarejestrowano 307557 indywidualnych działalności gospodarczych, co dało im dziewięciokrotną przewagę nad formami zorganizowanymi ${ }^{1}$. W styczniu 2017 roku zarejestrowano 2959 przedsiębiorstw jednoosobowych ${ }^{2}$. Dynamicznie zmieniająca się rzeczywistość stanowi nowe i niezwykle trudne wyzwanie dla jednoosobowego przedsiębiorcy. Immanentnym elementem gry rynkowej jest ryzyko działalności gospodarczej. Wymagania formalne prowadzenia działalności jednoosobowej są właściwie minimalne - niskie koszty prowadzenia oraz nieskomplikowane zasady jej założenia. To wygodna forma szczególnie dla początkującego przedsiębiorcy. Jednakże gdy działalność się rozrasta, może prowadzić do szeregu ryzyk prawnych. Za zobowiązania związane z prowadzonym przedsiębiorstwem przedsiębiorca odpowiada w sposób nieograniczony, a więc także swoim majątkiem osobistym. Dziedziczeniu przedsiębiorstwa jednoosobowego podlegają składniki majątkowe oraz zobowiązania, ale sama firma przypisana jest do określonej, indywidualnej osoby. Ponadto prowadzenie działalności gospodarczej uwarunkowane jest zmiennymi czynnikami mikroekonomicznymi i makroekonomicznymi.

Przedsiębiorcy jednoosobowi wykazują niższą świadomość ryzyka, jakie towarzyszy działalności gospodarczej. Świadomość ryzyka i ochrony przed nim ma tym większe znaczenie, im mniejsza skala działalności gospodarczej³. Efektywność działań przedsiębiorcy jednoosobowego oraz możliwość jego długoterminowego rozwoju zależą w dużym stopniu od jego zdolności przewidywania oraz gotowości na zmiany w przestrzeni gospodarczej i społeczno-politycznej ${ }^{4}$. Zarządzanie ryzykiem ma na celu jego identyfikację oraz obniżenie stopnia oddziaływania na funkcjonowanie przedsiębiorstwa. W niniejszej pracy autor przedstawił pojęcie oraz znamiona działalności gospodarczej w świetle ustawy o swobodzie działal-

${ }^{1}$ A. Witosz, A.J., Witosz, Prawo gospodarcze dla ekonomistów, LEX a Wolters Kluwer business, Warszawa 2015, s. 39.

${ }^{2}$ Rejestracja REGON 2017, https://egospodarka.pl [dostęp: 13.03.2018]

${ }^{3}$ J. Ropęga, Ścieżki niepowodzeń gospodarczych. Redukcja zagrożenia niepowodzeniem jako element strategii matej firmy, Wydawnictwo Uniwersytetu Łódzkiego, Łódź 2013, s. 171.

${ }^{4}$ K. Kreft, D. Wach, J. Winiarski, Ryzyko $w$ działalności gospodarczej przedsiębiorstw, InforGlobMar, Gdańsk 2014, s. 8-9. 
ności gospodarczej, problematykę rozpoczęcia i funkcjonowania przedsiębiorstwa jednoosobowego, wybrane rodzaje ryzyka jednoosobowej działalności gospodarczej oraz wybrane możliwości minimalizacji ryzyka. Cel artykułu stanowi analiza ryzyka jednoosobowej działalności gospodarczej oraz wskazanie możliwości jego minimalizacji w kontekście uregulowań prawnych w Polsce. Jako przykłady minimalizacji ryzyka zaproponowano rozwiązania w postaci przekształcenia przedsiębiorstwa jednoosobowego w spółkę prawa handlowego, mediacji, oceny wiarygodności finansowej kontrahenta oraz zabezpieczenia wierzytelności.

\section{Pojęcie oraz znamiona działalności gospodarczej w świetle ustawy o swobodzie dzialalności gospodarczej}

System nakazowo-rozdzielczy nie sprzyjał aktywności w sferze działalności gospodarczej. Opierając się na subiektywizmie, doprowadził do powszechnie krytykowanego zatarcia kryteriów obiektywnych oceny działalności gospodarczej, jej monopolizacji ${ }^{5}$, stagnacji, a w konsekwencji do kryzysu społeczno-gospodarcze$\mathrm{go}^{6}$. Zatem zadaniem pierwszoplanowym stało się wyzwolenie przedsiębiorczości i gospodarności oraz pobudzenie aktywności społecznej. W miejsce nakazu jako instrumentu sterowania działalnością gospodarczą wprowadzono zasadę wolności gospodarczej. Zasada wolności gospodarczej (swoboda działalności gospodarczej) wraz z wejściem w życie Konstytucji RP z dnia 2 kwietnia 1997 roku stała się zasadą konstytucyjną. W myśl powołanego aktu prawnego wolność gospodarcza może być ograniczona jedynie w drodze ustawy i tylko ze względu na ważny interes publiczny ${ }^{7}$. Podstawowy akt normatywny stanowi ustawa o swobodzie działalności gospodarczej z 2004 roku$^{8}$. Podstawy prawne działalności gospodarczej wyznacza system źródeł prawa przyjęty w Konstytucji RP uzupełniony prawem Unii Europejskiej. Potrzeba dalszej liberalizacji zasad działalności gospodarczej była podstawową przesłanką uchwalenia obecnie obowiązującej ustawy. Ustawa ta pełni rolę podstawowego aktu prawa (lex generalis). Określa

${ }^{5}$ K. Kruczalak, Pojęcie przedsiębiorcy i jego znaczenie $w$ obowiąujacym prawie, „Rejent” 1998, nr 3 (83), s. 11-22.

${ }^{6}$ W. Baka, Polska reforma gospodarcza, [w:] L. Bar (red.) Ocena regulacji prawnej reformy gospodarczej, „Państwo i Prawo” 1984, nr 5, s. 96-100.

${ }^{7}$ K. Kruczalak, Wolność gospodarcza i jej ograniczenia w świetle Konstytucji RP, „Gdańskie Studia Prawnicze" 1998, t. 3, s. 43-52.

${ }^{8}$ K. Kruczalak, Prawo handlowe. Zarys wyktadu, Wydawnictwo Prawnicze LexisNexis, Warszawa 2008, s. 61. 
ona tryb i zasady podejmowania oraz wykonywania działalności gospodarczej na terytorium Rzeczpospolitej Polskiej9 .

Działalność gospodarcza może być rozumiana w szerokim ujęciu jako wszelkie działania podejmowane w sferze gospodarki o charakterze ekonomicznym czy politycznym ${ }^{10}$. Pojęcie działalności gospodarczej występuje zarówno w doktrynie prawa, jak i w naukach ekonomicznych ${ }^{11}$. Aktualnie obowiązujący w prawie polskim zakres znaczeniowy oraz konstrukcja pojęć „działalność gospodarcza” i ,przedsiębiorca” zostały wypracowane w toku ewolucji. Oba terminy trwale zakorzeniły się w polskim systemie prawa. Stały się zwrotami powszechnie wykorzystywanymi, z którymi wiele aktów normatywnych wiąże określone skutki prawne. Ich kształt był i nadal jest konsekwencją aktualnych potrzeb i tez wskazywanych $\mathrm{w}$ orzecznictwie i doktrynie ${ }^{12}$. Definicję legalną działalności gospodarczej zawiera ustawa o swobodzie działalności gospodarczej. Wyznacza ona ramy prawne podejmowania i wykonywania działalności gospodarczej w Polsce. Artykuł 2 niniejszej ustawy stanowi, iż działalnością gospodarczą jest ,zarobkowa działalność wytwórcza, budowlana, handlowa, usługowa oraz poszukiwanie, rozpoznawanie i wydobywanie kopalin ze złóż, a także działalność zawodowa, wykonywana w sposób zorganizowany i ciągły"13. Powyższa definicja opiera się na trzech przesłankach: ekonomiczna klasyfikacja działalności, zarobkowy jej charakter oraz wykonywanie działalności w sposób zorganizowany i ciągły.

\section{Rozpoczęcie oraz funkcjonowanie jednoosobowej działalności gospodarczej}

Obowiązkiem odnoszącym się do wszystkich przedsiębiorców jest obowiązek wpisu do właściwego rejestru. Dla jednoosobowego przedsiębiorcy stosuje się szereg przepisów odnoszących się do przedsiębiorców w ogóle. Prowadzenie jednoosobowej działalności gospodarczej ma swoją specyfikę. Z kilku powodów pozycja przedsiębiorcy jednoosobowego jest wyjątkowa:

${ }^{9}$ Ustawa z dnia 2 lipca 2004 r. o swobodzie działalności gospodarczej (Dz.U. 2016, poz. 1829).

${ }^{10}$ T. Duraj, Prawna perspektywa pracy na własny rachunek, [w:] E. Kryńska (red.) Praca na wlasny rachunek - determinanty i implikacje, IPPiS, Warszawa 2007, s. 19.

${ }^{11}$ B. Chludziński, Pojęcie działalności gospodarczej i formy jej reglamentacji, „Studia Iuridica Toruniensia" 2006, t. 3, s. 43.

${ }^{12} \mathrm{M}$. Etel, Pojęcie przedsiębiorcy w prawie polskim i prawie Unii Europejskiej oraz w orzecznictwie sądowym, LEX a Wolters Kluwer business, Warszawa 2012, s. 169-170.

${ }^{13}$ Ustawa z dnia 2 lipca 2004 r. o swobodzie działalności gospodarczej (Dz.U. z 2016 r., poz. 1829). 
a) zgłoszenie działalności gospodarczej do Centralnej Ewidencji i Informacji o Działalności Gospodarczej;

b) posiadanie odpowiedniej zdolności do czynności prawnych;

c) wpływ współmałżonka na podejmowane czynności (ustrój majątkowy małżeński);

d) odpowiedzialność za zobowiązania całym swoim majątkiem osobistym;

e) możliwość przekształcenia w spółkę kapitałową ${ }^{14}$.

$\mathrm{Z}$ art. 2 ustawy o swobodzie działalności gospodarczej wynikają następujące cechy prowadzenia działalności gospodarczej przez jednoosobowego przedsiębiorcę:

a) prowadzenie działalności wytwórczej, handlowej, budowlanej, usługowej (prowadzenie przedsiębiorstwa w znaczeniu funkcjonalnym). Ponadto w oparciu o prowadzenie przedsiębiorstwa można wyodrębnić kompleks majątkowy (przedsiębiorstwo w znaczeniu przedmiotowym);

b) zarobkowy charakter działalności (podstawowy cel stanowi osiągnięcie zysku). Nie wyklucza to działalności na przykład dobroczynnej;

c) działalnością gospodarczą jest również działalność zawodowa (funkcjonowanie tak zwanych wolnych zawodów);

d) wykonywanie działalności w sposób zorganizowany i ciągły ${ }^{15}$.

Osoby fizyczne wykonujące działalność gospodarczą są zobowiązane uzyskać wpis do Centralnej Ewidencji i Informacji o Działalności Gospodarczej (CEIDG). W przypadku innych przedsiębiorców wymagany jest wpis do Krajowego Rejestru Sądowego. Wpis do CEIDG stanowi obowiązek przedsiębiorcy i powoduje domniemanie statusu przedsiębiorcy ${ }^{16}$. Ewidencję w systemie teleinformatycznym prowadzi minister właściwy do spraw gospodarki (ponadto taką ewidencję prowadzi gmina). Organem właściwym do dokonania wpisu jest wójt, burmistrz lub prezydent miasta właściwy miejscowo ze względu na miejsce zamieszkania wnioskującego ${ }^{17}$. Przekazywanie danych i informacji do CEIDG oraz przekazywanie ich z CEIDG odbywa się za pośrednictwem platformy usług administracji publicznej lub w inny sposób za pomocą środków komunikacji elektronicznej. Wnioski o wpis oraz inne dane przekazywane są do Centralnej Ewidencji i Informacji o Działalności Gospodarczej za pośrednictwem elektronicznych formularzy, zamieszczonych na stronie internetowej, na elektronicznej platformie usług administracji publicznej oraz w Biuletynie Informacji Publicznej ministra właściwego do spraw gospodarki ${ }^{18}$. Wpis ma charakter deklaratoryjny i jest bezpłatny. Wnioski o wpis są wolne od opłat. Wpisowi podlegają dane wska-

${ }^{14}$ A. Kidyba, Prawo handlowe, C.H. Beck, Warszawa 2016, s. 227.

${ }^{15}$ Ibidem.

${ }^{16}$ M. Domagała, Aspekty prawne prowadzenia działalności gospodarczej, [w:] J. Izdebski, Prawne i organizacyjne aspekty wykonywania działalności gospodarczej. Działalność organizacyjna typu spin off $i$ spin out, Katolicki Uniwersytet Lubelski Jana Pawła II, Lublin 2010, s. 12.

${ }^{17}$ Ibidem, s. 13

${ }^{18}$ A. Kidyba, Prawo handlowe..., s. 87-95. 
zane w art. 25. ustawy o swobodzie działalności gospodarczej, między innymi firma przedsiębiorcy, REGON, NIP, informacja o istnieniu lub ustaniu małżeńskiej wspólności majątkowej czy data rozpoczęcia wykonywania działalności gospodarczej. Integralną część wniosku stanowi żądanie: wpisu bądź zmiany wpisu do krajowego rejestru urzędowego podmiotów gospodarki narodowej (REGON), zgłoszenia płatnika składek albo jego zmiany w rozumieniu przepisów o systemie ubezpieczeń społecznych lub zgłoszenia oświadczenia o kontynuowaniu ubezpieczenia społecznego rolników w rozumieniu przepisów o ich ubezpieczeniu, zgłoszenia identyfikacyjnego albo aktualizacyjnego, o którym mowa w przepisach o zasadach ewidencji oraz identyfikacji płatników i podatników, przyjęcia oświadczenia o wyborze przez przedsiębiorcę formy opodatkowania podatkiem dochodowym od osób fizycznych, lub wniosku o zastosowanie opodatkowania w formie karty podatkowej. Ponadto wnioskodawca może dołączyć do wniosku zgłoszenie aktualizacyjne lub rejestracyjne. Ma obowiązek złożenia oświadczenia o braku orzeczonych zakazów prowadzenia działalności bądź wykonywania zawodu ${ }^{19}$. Dodatkowo, nie później w dniu roboczym następującym po dokonaniu wpisu wnioskodawca zobowiązany jest przesłać za pośrednictwem środków komunikacji elektronicznej określone dane do właściwego Naczelnika Urzędu Skarbowego, a po uzyskaniu informacji o nadanym mu numerze NIP do Zakładu Ubezpieczeń Społecznych (ZUS) albo Kasy Rolniczego Ubezpieczenia Społecznego (KRUS) oraz do Głównego Urzędu Statystycznego (GUS) ${ }^{20}$. Osoba, która składa wniosek za pomocą formularza elektronicznego opatruje go podpisem elektronicznym, weryfikowanym za pomocą kwalifikowanego certyfikatu, zachowując zasady przewidziane w przepisach o podpisie elektronicznym. Wnioskodawca może złożyć wniosek także na formularzu zgodnym z elektronicznym formularzem wzorcowym w wybranym przez niego urzędzie gminy, opatrując go własnoręcznym podpisem lub listem poleconym (wraz z potwierdzoną przez notariusza własnoręcznością podpisu wnioskodawcy). W takim przypadku organ gminy potwierdza tożsamość wnioskującego oraz przyjęcie wniosku, a w następnej kolejności przekształca ten wniosek na formę dokumentu elektronicznego (opatruje go podpisem elektronicznym weryfikowanym za pomocą kwalifikowanego certyfikatu bądź podpisuje w inny sposób wskazany w art. 26 ust. 4 ustawy o swobodzie działalności gospodarczej), umożliwiając identyfikację wnioskodawcy. Organ gminy przesyła wniosek do CEIDG nie później niż następnego dnia roboczego, licząc od dnia jego otrzymania. Informacje oraz dane udostępniane przez CEIDG są jawne ${ }^{21}$. Wpis do Centralnej Ewidencji i Informacji o Działalności Gospodarczej stanowi warunek podjęcia działalności gospodarczej. Określe-

${ }^{19}$ B. Gnela, Prawo handlowe dla ekonomistów, Wolters Kluwer, Warszawa 2016, s. 30-34.

${ }^{20}$ Centralna Ewidencja i Informacja o Działalności Gospodarczej, https://prod.ceidg.gov.pl [dostęp: 4.03.2018].

${ }^{21}$ B. Gnela, Prawo handlowe..., s. 30-34. 
nie przez przedsiębiorcę daty rozpoczęcia działalności wpisywanej do ewidencji powoduje istnienie domniemania faktycznego, iż $\mathrm{z}$ tą datą została ona podjęta i była prowadzona do momentu wykreślenia jej z ewidencji ${ }^{22}$.

Osoba fizyczna ma obowiązek uzyskania licencji, zezwolenia lub koncesji (względnie wpisu do rejestru działalności regulowanej) w przypadku, gdy przepisy prawa wymagają tego ze względu na rodzaj prowadzonej działalności. Jednoosobowy przedsiębiorca musi również zapewnić, aby czynności podejmowane w ramach prowadzonej działalności wykonywane były przez osoby legitymujące się odpowiednimi kwalifikacjami. Zgodnie z art. 22 ustawy o swobodzie działalności gospodarczej przedsiębiorcy muszą posługiwać się rachunkiem bankowym w zakresie prowadzonej działalności, uzyskać tak zwany numer REGON (Ogólny System Identyfikacji i Klasyfikacji Gospodarki Narodowej) ${ }^{23}$, zgłosić się do ewidencji podatkowej NIP24, fakultatywnie uzyskać status zarejestrowanego podatnika podatku VAT, zawiadomić odpowiedni organ o posiadaniu rachunku bankowego (ZUS, Urząd Skarbowy). Aktualnie powyższe czynności realizowane są w ramach zasady ,jednego okienka" (one-stop shop). Żądania zgłoszeń i wpisów do wskazanych ewidencji i rejestrów stanowią integralną część wniosku o wpis ${ }^{25}$.

\section{Rodzaje ryzyka jednoosobowej dzialalności gospodarczej}

Dynamicznie zmieniająca się rzeczywistość gospodarcza, społeczna i polityczna stanowi trudne wyzwanie dla jednoosobowej działalności gospodarczej. Jednoosobowa działalność to specyficzna forma aktywności gospodarczejej ${ }^{26}$. Za zobowiązania związane z prowadzonym przedsiębiorstwem przedsiębiorca odpowiada w sposób nieograniczony, a więc także swoim majątkiem osobistym. Wierzyciele mogą żądać egzekucji zarówno z przedmiotów, które indywidualny przedsiębiorca nabył w ramach prowadzonej działalności (na przykład samochód, wyposażenie) jak również ze składników jego majątku prywatnego, których nabycie nie pozostaje w związku z prowadzoną działalnością (niezależnie od tego, czy przedmioty nabyte zostały przed rozpoczęciem, w trakcie czy po zakończeniu prowadzenia działalności). Ponadto zarówno wierzyciele przedsiębiorstwa, jak i wierzyciele osobiści mogą egzekwować swe należności ${ }^{27}$.

22 A. Kidyba, Prawo handlowe..., s. 229.

${ }^{23}$ Ustawa z dnia 29 czerwca 1995 r. o statystyce publicznej (Dz.U. z 2012 r., poz. 591 ze zm.).

${ }^{24}$ Ustawa z dnia 13 października 1995 r. o zasadach ewidencji i identyfikacji podatników i płatników (Dz.U. z 2012 r., poz. 1314 ze zm.).

${ }^{25}$ A. Kidyba, Prawo handlowe..., s. 228-229.

${ }^{26} \mathrm{M}$. Gajewska, Metody pomiaru rezultatów funkcjonowania jednoosobowej działalności gospodarczej, „Nauki o Zarządzaniu - Management Sciences” 2012, nr 3(12), s. 66.

27 A. Kidyba, Prawo handlowe..., s. 234. 
W przypadku prowadzenia działalności gospodarczej przez osoby fizyczne pozostające w związku małżeńskim (jeśli małżeńska wspólność majątkowa nie została wyłączona bądź uchylona) mogą pojawić się problemy w związku z zarządem majątkiem wspólnym oraz odpowiedzialnością za zobowiązania składnikami wspólnego majątku. Zgodnie z art. $31 \S 1 \mathrm{KRO}$, z chwilą zawarcia małżeństwa co do zasady powstaje między małżonkami wspólność majątkowa (wspólność ustawowa), która obejmuje przedmioty majątkowe nabyte w czasie jej trwania przez jednego z małżonków lub przez oboje $\mathrm{z}$ nich ${ }^{28}$. Do majątku wspólnego należą między innymi pobrane wynagrodzenie za pracę oraz dochody $z$ innej działalności zarobkowej, dochody z majątku wspólnego oraz z majątku osobistego każdego z małżonków, środki zgromadzone na rachunku otwartego lub pracowniczego funduszu emerytalnego oraz kwoty składek zewidencjonowanych na subkoncie (art. $31 \S 2 \mathrm{KRO})^{29}$. Małżonkowie obowiązani są współdziałać w zarządzie majątkiem wspólnym. Notabene, przedmiotami majątkowymi, które służą małżonkowi do prowadzenia działalności zarobkowej małżonek-przedsiębiorca może co do zasady zarządzać samodzielnie. Jednakże zgoda drugiego małżonka potrzebna jest do dokonania:

a) czynności prawnej, prowadzącej do zbycia, obciążenia, odpłatnego nabycia nieruchomości lub użytkowania wieczystego, a także prowadzącej do oddania nieruchomości do używania bądź pobierania z niej pożytków;

b) czynności prawnej prowadzącej do zbycia, obciążenia, odpłatnego nabycia prawa rzeczowego, którego przedmiot stanowi lokal lub budynek;

c) czynności prawnej prowadzącej do zbycia, obciążenia, odpłatnego nabycia oraz wydzierżawienia gospodarstwa rolnego bądź przedsiębiorstwa;

d) co do zasady darowizny z majątku wspólnego ${ }^{30}$.

Wierzyciel może żądać zaspokojenia należności ze wspólnego majątku wyłącznie w przypadku, gdy małżonek zaciągnął zobowiązania za zgodą drugiego małżonka. Umowy zawierane przez jednoosobowego przedsiębiorcę pozostającego w ustroju wspólności majątkowej wymagać będą (w interesie kontrahenta) wyrażonej przez małżonka zgody. W przypadku braku zgody wierzyciel może żądać zaspokojenia wyłącznie z majątku osobistego dłużnika, wynagrodzenia za pracę bądź też dochodów, które dłużnik uzyskał z innej zarobkowej działalności, praw własności przemysłowych oraz innych praw twórcy, przynależnych mu praw autorskich i praw pokrewnych oraz przedmiotów majątkowych wchodzących w skład przedsiębiorstwa, o ile wierzytelność powstała w związku z jego prowadzeniem. Powyższa regulacja może skutkować powstaniem tytułów wykonawczych niemożliwych do wyegzekwowania. W praktyce znaczna część mająt-

${ }^{28}$ Ustawa z dnia 25 lutego 1964 r. - kodeks rodzinny i opiekuńczy (Dz.U. z 1964 r. Nr 9 , poz. 59).

${ }^{29}$ Ibidem. 
ku przedsiębiorcy jednoosobowego znajduje się w majątku wspólnym, a składniki przedsiębiorstwa najczęściej są obciążone bądź też nie stanowią jego własności (leasing, najem) ${ }^{31}$. Celem uzyskania klauzuli wykonalności przeciwko współmałżonkowi wierzyciel musi wykazać dokumentem urzędowym bądź prywatnym, iż zatwierdzona tytułem egzekucyjnym wierzytelność powstała z czynności prawnej dokonanej za zgodą małżonka dłużnika (art. $787 \mathrm{KPC})^{32}$. Ustawodawca poprzez nowelizację Kodeksu rodzinnego i opiekuńczego, wprowadzoną ustawą z dnia 7 września 2007 r. o pomocy osobom uprawnionym do alimentów przyznaje wierzycielom osoby, która pozostaje w związku małżeńskim prawo żądania ustanowienia przez sąd rozdzielności majątkowej. Uprawdopodobnienie, iż zaspokojenie wierzytelności stwierdzonej tytułem wykonawczym wymaga dokonania podziału majątku wspólnego stanowi podstawę wytoczenia przedmiotowego powództwa ${ }^{33}$. Odpowiedzialność podatkowa w przypadku osób pozostających w związku małżeńskim obejmuje majątek odrębny podatnika, a także majątek wspólny podatnika i jego małżonka ${ }^{34}$.

Jedna $\mathrm{z}$ wad jednoosobowej działalności gospodarczej ujawnia się w przypadku sukcesji po śmierci przedsiębiorcy. Niezależnie od tego, czy przedsiębiorstwo zostanie odziedziczone na podstawie rozrządzenia na wypadek śmierci, ustawy czy zapisu windykacyjnego nie jest możliwa jego pełna kontynuacja. Wpisy do CEIDG, REGON czy NIP nie stanowią elementów spadku. Spadkobierca musi założyć własną działalność gospodarczą. Taka konieczność dotyczy również przejścia zakładu pracy na spadkobiercę. Sytuację spadkobiercy utrudnia dodatkowo to, iż prawa i obowiązki przedsiębiorcy uzyskane na podstawie decyzji administracyjnej wygasają z chwilą śmierci spadkodawcy. Każdorazowo wymaga się zbadania treści umów leasingowych czy kredytowych pod kątem postępowania w związku z sukcesją. Najwięcej trudności pojawia się w sytuacji, gdy istnieje kilku spadkodawców, a w skład spadku poza przedsiębiorstwem wchodzą również inne składniki majątkowe. W tym przypadku kontynuacja działalności gospodarczej wymaga przeprowadzenia działu spadku w postępowaniu sądowym lub $\mathrm{w}$ drodze umowy zawartej formie aktu notarialnego. Postępowanie sądowe może być długotrwałe, co z kolei może mieć wpływ na sprawność prowadzenia działalności i doprowadzić do utraty kontraktów ${ }^{35}$.

${ }^{31}$ A. Kidyba, Prawo handlowe..., s. 234-235.

${ }^{32}$ Ustawa z dnia 17 listopada 1964 r. - kodeks postępowania cywilnego (Dz.U.2016.0.1822).

${ }^{33}$ A. Kidyba, Prawo handlowe..., s. 235-236.

${ }^{34}$ Ustawa z dnia 29 sierpnia 1997 r. - ordynacja podatkowa (Dz.U. z 2017 r., poz. 201 ze zm.) art. $26,29,111$.

${ }^{35}$ I. Bąkowski, Sukcesja indywidualnej działalności gospodarczej, „Dziennik Gazeta Prawna” 2015, nr 204 (4097), Procedury, s. 7. 


\section{Minimalizacja ryzyka jako kluczowy czynnik wpływający na sukces przedsiębiorstwa}

Zarządzanie ryzykiem stanowi proces złożony. W pierwszej kolejności konieczna wydaje się jego identyfikacja, a w następnym etapie - minimalizacja ${ }^{36}$. Jako przykłady minimalizacji ryzyka jednoosobowego przedsiębiorstwa zaproponowano rozwiązania w postaci mediacji, oceny wiarygodności finansowej kontrahenta, zabezpieczenia wierzytelności oraz przekształcenia przedsiębiorstwa jednoosobowego w spółkę prawa handlowego.

Nieterminowa realizacja zobowiązań kontrahenta stanowi obecnie znaczący problem w prowadzeniu działalności gospodarczej. Przed skierowaniem określonej sprawy na drogę postępowania sądowego przedsiębiorca może skorzystać ze sposobów pozasądowego bądź przedsądowego uzyskania spełnienia świadczenia. Podstawowym narzędziem jest mediacja jako poufne i dobrowolne poszukiwanie porozumienia. Narzędzie prewencyjne stanowi natomiast ocena wiarygodności finansowej kontrahenta. Warto ją sprawdzić przed podjęciem określonej decyzji w przedsiębiorstwie. Do tego celu służą rejestry urzędowe oraz prywatne. Rejestry realizują funkcje ewidencyjne, informacyjne i ochronne. Wpisy stwarzają możliwość zapoznania się z sytuacją majątkową podmiotu i w oparciu o nią pozwalają na ocenę ryzyka. Do publicznych rejestrów zalicza się dwa sądowe zbiory danych, które należą do Krajowego Rejestru Sądowego - dział czwarty rejestru przedsiębiorców oraz rejestr dłużników niewypłacalnych. Biura Informacji Gospodarczej (BIG) oraz Biuro Informacji Kredytowej (BIK) stanowią rejestry prywatne. W dziale czwartym rejestru przedsiębiorców znajdują się informacje o publicznoprawnych (m.in. zaległości podatkowe i celne) i prywatnoprawnych (m.in. wierzytelność oraz oznaczenie wierzyciela) należnościach. Rejestr dłużników niewypłacalnych ma na celu zapewnienie aktualnego i szybkiego dostępu do informacji związanych z wiarygodnością potencjalnych kontrahentów. Do rejestru dłużników wpisuje się z urzędu po spełnieniu określonych przesłanek podmiotowych. Podmiotem o statusie szczególnym o systemie wymiany gospodarczej jest BIG. Nadzór nad jego działalnością sprawuje minister właściwy do spraw gospodarki. Rejestr ten charakteryzuje warunkowa i względna jawność. Informacja gospodarcza udostępniana jest na komercyjnych zasadach (co do zasady odpłatnie). Biuro Informacji Kredytowej stanowi bazę danych o wszystkich spłacanych kredytach. Dane przekazywane do BIK nie dotyczą kwot, a zawierają informacje o korzystaniu z produktów kredytowych i terminowości spłacania rat. Mogą być udostępniane bankom oraz innym instytucjom upoważnionym do

${ }^{36}$ A. Mikulska, Zarządzanie ryzykiem jako wymiar strategicznego i przedsiębiorczego podejścia do zarządzania małym i średnim przedsiębiorstwem. „Marketing i Rynek” 2015, nr 9, s. $412-423$. 
udzielania kredytów. Informacje dotyczące sytuacji finansowej kontrahenta uzyskiwane są ze sprawozdań finansowych ${ }^{37}$.

W przypadku odpowiedzialności osobistej zasadą jest, iż dłużnik ponosi odpowiedzialność osobistą za obciążający go dług. Odpowiada zarówno całym majątkiem, który znajduje się w jego posiadaniu w chwili zaspokajania wierzyciela, jak i majątkiem przyszłym. Wierzyciel zaspokaja się w drodze postępowania egzekucyjnego. Ponadto co do zasady odpowiedzialność osobista powinna trwać do momentu całkowitego uzyskania wierzytelności przez wierzyciela. W praktyce odpowiedzialność osobista obciążona jest ryzykiem, iż w przyszłym majątku dłużnika nie będzie środków, które wystarczyłyby na pokrycie wszystkich długów. Przy tym rodzaju odpowiedzialności dłużnik nie jest ograniczony w możliwości rozporządzania swym majątkiem - powyższe ryzyko obciąża wierzyciela. Wierzyciel powinien więc zabezpieczyć swoją wierzytelność. Wyróżnia się zabezpieczenia osobiste oraz rzeczowe. Istotę zabezpieczeń osobistych stanowi rozszerzenie zakresu ochrony wierzyciela poprzez powołanie do odpowiedzialności dodatkowego dłużnika, nie będącego bezpośrednią stroną transakcji. Formy zabezpieczeń osobistych, które w obrocie gospodarczym mają najszersze zastosowanie to m.in. przystąpienie do długu (wraz z konstrukcją solidarności), weksel i poręczenie wekslowe, poręczenie czy gwarancja bankowa ${ }^{38}$. Podstawę powstania poręczenia stanowi umowa. Poręczyciel zobowiązuje się wykonać zobowiązanie względem wierzyciela na wypadek, gdyby nie uczynił tego dłużnik ${ }^{39}$. To zabezpieczenie osobiste ma charakter akcesoryjny. Istnienie oraz rozmiar zobowiązania poręczyciela zależy od długu głównego. Dzieli ono los zobowiązania dłużnika. W przypadku, gdy wierzyciel uzyskuje zaspokojenie bądź zobowiązanie wygasa z innej przyczyny, wygasa również zobowiązanie poręczyciela. Poręczenie może zabezpieczać całość wierzytelności lub być ograniczone do określonej sumy. Poręczać można także za dług przyszły (skuteczność zależna od wskazania w umowie górnej granicy odpowiedzialności) ${ }^{40}$. Wzmocnienie ochrony wierzyciela stanowi sytuacja, w której kilka osób wspólnie ponosi odpowiedzialność za jeden dług. Solidarność bierna jest podstawową konstrukcją prawną, która umożliwia osiągnięcie powyższego rezultatu. Może ona wynikać bezpośrednio z przepisów prawa lub powstać wolą samych zainteresowanych ${ }^{41}$. Wskazana instytucja wzmacnia pozycję wierzyciela. Może on żądać całości zobowiązania od każdego z dłużników. Dopiero całkowite wykonanie zobowiązania ostatecznie zwalnia dłużników z odpowiedzialności.

Minimalizację ryzyka związanego $\mathrm{z}$ przedsiębiorstwem jednoosobowym może stanowić jego przekształcenie w bardziej złożoną strukturę organizacyjną

${ }^{37}$ A. Witosz, A.J. Witosz, Prawo gospodarcze dla ekonomistów, LEX a Wolters Kluwer business, Warszawa 2015, s. 202.

${ }^{38}$ Ibidem, s. 198-204.

${ }^{39}$ Ustawa z dnia 23 kwietnia 1964 r. - Kodeks cywilny (Dz.U. 2017.0.459) (art. 876).

${ }^{40}$ W. Czachurski, Zobowiazania..., s. 567-570.

${ }^{41}$ Ustawa z dnia 23 kwietnia 1964 r. - Kodeks cywilny (Dz.U. 2017.0.459) (art. 366-367). 
i tym samym ograniczenie odpowiedzialności za zobowiązania do masy majątkowej przedsiębiorstwa. Liczba przedsiębiorców indywidualnych służy do ukazania zaangażowania obywateli w przedsiębiorczość. Jednakże podstawę owej przedsiębiorczości i główne źródło rozwoju gospodarczego stanowią spółki handlowe. Wynika to również z ich korporacyjnego charakteru jako powstających w wyniku umowy wspólników oraz angażujących swój majątek dla wspólnego celu, którym poza prowadzeniem przedsiębiorstwa jest uzyskanie dochodów umożliwiających dalszy rozwój spółki i podział zysku. Kodeks spółek handlowych (KSH) wprowadza spółki w postaci spółki jawnej, spółki partnerskiej, spółki komandytowej, spółki komandytowo-akcyjnej (spółki osobowe) oraz spółki z ograniczoną odpowiedzialnością i spółki akcyjnej (spółki kapitałowe) ${ }^{42}$. Podjęcie decyzji o przekształceniu przedsiębiorstwa jednoosobowego i wybór jednej z możliwości z całą pewnością wymaga szczegółowej analizy aspektów formalno-prawnych oraz analizy zestawienia korzyści i wad poszczególnych przekształceń. Czy warto przekształcić jednoosobową działalność gospodarczą w spółkę? Zalet takiego rozwiązania jest niewątpliwie kilka. Jedną z korzyści przekształcenia przedsiębiorcy w spółkę kapitałową jest przejęcie przez nią - w ramach sukcesji uniwersalnej - praw i obowiązków przedsiębiorcy. Spółka przekształcona jest co do zasady podmiotem tych samych praw i obowiązków, co przedsiębiorca przekształcany (osoba fizyczna) na gruncie administracyjno-prawnym i cywilnoprawnym. Pozostaje podmiotem koncesji, ulg czy zezwoleń przyznanych przedsiębiorcy przed jego przekształceniem, chyba że ustawa bądź decyzja o udzieleniu zezwolenia, koncesji lub ulgi stanowi inaczej ${ }^{43}$. Osoba fizyczna, która przed przekształceniem wykonywała własną działalność gospodarczą odpowiada solidarnie ze spółką przekształconą za zobowiązania przekształcanego przedsiębiorcy związane z prowadzoną działalnością gospodarczą, powstałe przed dniem przez okres trzech lat od dnia przekształcenia $^{44}$. Przepisy dotyczące przekształcenia przedsiębiorstwa jednoosobowego tworzą sformalizowaną strukturę w celu zapewnienia prawidłowości tego procesu.

\section{Podsumowanie}

Zgodnie z podmiotowym zakresem pojęcia przedsiębiorcy na pierwszym planie występuje osoba fizyczna. To zrozumiałe, gdyż człowiek ma zawsze zdolność prawną i jest naturalne, iż od wieków zajmuje się przedsiębiorczością. Obecnie ma ona często inny wymiar niż w chwili, gdy łączona była z drobnym handlem

\footnotetext{
${ }^{42}$ Ustawa z dnia 15 września 2000 r. - Kodeks spółek handlowych (Dz.U.2017.0.1577) (art. 2).

${ }^{43}$ Ustawa z dnia 15 września 2000 r. - Kodeks spółek handlowych (Dz.U.2017.0.1577) (art. $584^{2} \S 1$ i 2 ).

${ }^{44}$ Ustawa z dnia 15 września 2000 r. - Kodeks spółek handlowych (Dz.U.2017.0.1577) $\left(\operatorname{art.} 584^{13}\right)$.
} 
czy wytwórczością rzemieślniczą. Indywidualny przedsiębiorca będący osobą fizyczną jest często małym lub mikroprzedsiębiorcą. Ze względu na niskie koszty prowadzenia oraz nieskomplikowane zasady założenia jednoosobowa działalność gospodarcza stanowi najczęściej wybieraną formę prowadzenia działalności gospodarczej. Taka forma wydaje się wygodna dla początkującego przedsiębiorcy. Jednakże gdy działalność się rozrasta, może nieść za sobą szereg ryzyk prawnych bądź finansowych. Świadomość ryzyka i ochrony przed nim ma tym większe znaczenie im mniejsza skala działalności gospodarczej.

W opracowaniu wskazano na węzłowe problemy związane z funkcjonowaniem jednoosobowej działalności gospodarczej w kontekście uregulowań prawnych w Polsce. Jako przykłady minimalizacji ryzyka przedsiębiorstwa jednoosobowego zaproponowano rozwiązania w postaci mediacji, oceny wiarygodności finansowej kontrahenta, zabezpieczenia wierzytelności oraz przekształcenia jednoosobowego przedsiębiorstwa w bardziej złożoną strukturę i tym samym ograniczenia odpowiedzialności za zobowiązania do masy majątkowej przedsiębiorstwa. Zdaniem autora minimalizacja ryzyka działalności gospodarczej stanowi bowiem o jej przyszłym sukcesie.

\section{Bibliografia}

Baka W., Polska reforma gospodarcza, [w:] L. Bar (red.) Ocena regulacji prawnej reformy gospodarczej, „Państwo i Prawo” 1984, nr 5.

Bąkowski I., Sukcesja indywidualnej działalności gospodarczej, „Dziennik Gazeta Prawna” 2015, nr 204 (4097), Procedury.

Centralna Ewidencja i Informacja o Działalności Gospodarczej, https://prod.ceidg.gov.pl [dostęp: 4.03.2018].

Chludziński B., Pojęcie działalności gospodarczej i formy jej reglamentacji, „Studia Iuridica Toruniensia" 2006, t. 3.

Czachurski W., Zobowiazania. Zarys wyktadu, Wolters Kluwer, Warszawa 2009.

Domagała M., Aspekty prawne prowadzenia działalności gospodarczej, [w:] J. Izdebski, Prawne i organizacyjne aspekty wykonywania działalności gospodarczej. Działalność organizacyjna typu spin off $i$ spin out, Katolicki Uniwersytet Lubelski Jana Pawła II, Lublin 2010.

Duraj T., Prawna perspektywa pracy na własny rachunek, [w:] E. Kryńska (red.) Praca na własny rachunek - determinanty i implikacje, IPPiS, Warszawa 2007.

Etel M., Pojęcie przedsiębiorcy w prawie polskim i prawie Unii Europejskiej oraz $w$ orzecznictwie sadowym, LEX a Wolters Kluwer business, Warszawa 2012.

Gajewska M., Metody pomiaru rezultatów funkcjonowania jednoosobowej działalności gospodarczej, „Nauki o Zarządzaniu - Management Sciences” 2012, nr 3 (12).

Gnela B., Prawo handlowe dla ekonomistów, Wolters Kluwer, Warszawa 2016.

Kidyba A., Prawo handlowe, C.H. Beck, Warszawa 2016.

Kreft D., Wach D., Winiarski J., Ryzyko w działalności gospodarczej przedsiębiorstw, InforGlobMar, Gdańsk 2014. 
Kruczalak K., Pojęcie przedsiębiorcy i jego znaczenie w obowiązującym prawie, „Rejent” 1998, $\mathrm{nr} 3$ (83).

Kruczalak K., Prawo handlowe. Zarys wyktadu, Wydawnictwo Prawnicze LexisNexis, Warszawa 2008.

Kruczalak K., Wolność gospodarcza i jej ograniczenia w świetle Konstytucji RP, „Gdańskie Studia Prawnicze" 1998 , t. 3.

Mikulska A., Zarządzanie ryzykiem jako wymiar strategicznego i przedsiębiorczego podejścia do zarządzania małym i średnim przedsiębiorstwem, „Marketing i Rynek” 2015, nr 9.

Ropęga J., Ścieżki niepowodzeń gospodarczych. Redukcja zagrożenia niepowodzeniem jako element strategii małej firmy, Wydawnictwo Uniwersytetu Łódzkiego, Łódź 2013.

Ustawa z dnia 25 lutego 1964 r. - kodeks rodzinny i opiekuńczy (Dz.U. 1964, nr 9 poz. 59).

Ustawa z dnia 23 kwietnia 1964 r. - Kodeks cywilny (Dz.U. 2017.0.459).

Ustawa z dnia 17 listopada 1964 r. - kodeks postępowania cywilnego (Dz.U.2016.0.1822).

Ustawa z dnia 29 czerwca 1995 r. o statystyce publicznej (Dz.U. 2012 r., poz. 591 ze zm.).

Ustawa z dnia 13 października 1995 r. o zasadach ewidencji i identyfikacji podatników i płatników (Dz.U. z 2012, poz. 1314 ze zm.).

Ustawa z dnia 29 sierpnia 1997 r. - ordynacja podatkowa (Dz.U. 2017 r., poz. 201 ze zm.).

Ustawa z dnia 15 września 2000 r. - Kodeks spółek handlowych (Dz.U.2017.0.1577).

Ustawa z dnia 2 lipca 2004 r. o swobodzie działalności gospodarczej (Dz.U. 2016, poz. 1829).

Witosz A., Witosz A.J., Prawo gospodarcze dla ekonomistów, LEX a Wolters Kluwer business, Warszawa 2015.

\section{Streszczenie}

W świetle ustawy o swobodzie działalności gospodarczej osoby fizyczne mogą prowadzić działalność gospodarczą jednoosobowo, występując wówczas samodzielnie jako przedsiębiorcy. Instytucja ta, jako najpowszechniejsza forma podejmowania działalności gospodarczej w Polsce, wypełnia znaczny fragment przestrzeni rynku pracy. Wymagania formalne prowadzenia jednoosobowej działalności gospodarczej są właściwie minimalne. Forma ta wydaje się wygodna dla początkującego przedsiębiorcy. Jednakże rozrastająca się jednoosobowa działalność gospodarcza może nieść za sobą szereg ryzyk prawnych bądź finansowych. W artykule wskazano na węzłowe problemy związane $\mathrm{z}$ funkcjonowaniem jednoosobowej działalności gospodarczej w kontekście uregulowań prawnych $\mathrm{w}$ Polsce. Jako przykłady minimalizacji ryzyka zaproponowano rozwiązania w postaci mediacji, oceny wiarygodności finansowej kontrahenta, zabezpieczenia wierzytelności oraz przekształcenia w spółkę prawa handlowego.

Słowa kluczowe: działalność gospodarcza, jednoosobowa działalność gospodarcza, ryzyko działalności gospodarczej, minimalizacja ryzyka

Numer klasyfikacji JEL: K22, L26 